Katalin G. Kállay

\title{
Mailing Versus Blackmailing
}

\section{Senses of Delivery in Edgar Allan Poe's “The Purloined Letter”}

What happens when one has to realise that something has been stolen from him or her in such a cunning manner that (s)he is incapable of doing anything against the act of purloining? The victim first becomes embarrassed, then irritated, maybe enraged, and (s)he, of course, will desperately want to get it back. In case the victim is equipped with the necessary courage and cunning (s)he might want to steal it back, exactly in the astonishing manner of the thief.

A reader, a man or woman of letters might become the victim of such a process when reading "The Purloined Letter," the literary example of a case described above. The thing so stolen is no less than the reader's trust in a "story proper," in a "manifold message," and thus in the possibility of the nondescript and vulnerable notion of catharsis. If one is not content with any of the various replacements, after becoming embarrassed and irritated (s)he will try to do whatever is intellectually possible in order to get it back. For this purpose, an extraordinary amount of courage and cunning is needed, since the thief is the author himself, who seems to take delight in confronting his reader with an emptiness in the heart of his story. And the act of purloining is so perfect that the emptiness might demonstrate to the victim that the thing stolen has never been in his or her possession, which is still not a proof of the fact that it does not exist.

1 All quotations from and references to the text are based on the following edition: Thomas Olive Mabbot, ed., Collected Works of Edgar Allan Poe: Tales and Sketches, 1843-1849 (London and Cambridge, Mass.: The Belknap Press and Harvard University Press, 1978) 972-997.

The AnaChronis T (2002) 151-163 ISSN 1219-2589 
How to steal it back, then? This short story is the third and last, in Poe's words "perhaps the best," 2 of a series of tales of ratiocination, celebrating the congenial and ingenious "analytical mind" of the master-detective, C. Auguste Dupin. How to compete with him in acumen?

The text begins with a serious warning in Latin: "Nil sapientiae odiosius acumine nimio" ("Nothing is more hateful to wisdom than too much cunning").

Knowing that this line is ascribed to Seneca but it has not been located by the philologists, and also knowing that itself was purloined by the author from an early version of "The Murders in the Rue Morgue" (the first tale of the series), ${ }^{3}$ can we, shall we take this warning to heart? In the name of wisdom, we must, even if we allow the possibility that the sentence is already part of the trick of purloining.

In the "Rue Morgue" version, the utterance is directed against G., the Prefect of the Parisian Police, who is "somewhat too cunning to be profound" - but is it certain that the target is the same here? In "The Purloined Letter," there are some people much better equipped with cunning than the half "entertaining" and half "contemptible" Prefect. The Minister D., both a practitioner and a victim of purloining, as well as of "analytical" exercises, who is a poet and a mathematician in one person, cannot possibly be devoid of acumen, not to mention Dupin himself. Considering that the motto did not appear in The Gift edition (the first publication of the story) ${ }^{4}$ but was a later insertion, one might even say that Poe managed to "seal" his tales of ratiocination with such a warning directed against his own method. And where is the terminus? Who can take the last step in this game of "set a thief to catch a thief?" Of course, it is the reader. But which reader?

In this case, there seems to be an almost endless chain of readers and readings. This particular text (and this particular game) has proved to be so powerful that - although the plot is very far from being sensational (especially as opposed to some of Poe's other stories) - it has managed to stir up such a sensation in recent critical and theoretical thinking that even a volume entitled

2 Poe wrote J. R. Lowell on 2nd July 1844 that ' 'The Purloined Letter,' forthcoming in 'the Gift' is perhaps the best of my tales of ratiocination" (Mabbot, p. 972).

3 Cf. the Motto in Mabbot, p. 993.

4 Cf. Mabbot, p. 973. 
The Purloined Poe $e^{5}$ had to be issued as a kind of testimony to its importance. Starting with Jacques Lacan's famous Seminar on "The Purloined Letter" (which, according to Jacques Derrida, already partly refigures Marie Bonaparte's Freudian interpretation), many outstanding critics have answered the challenge: Derrida's "La Facteur de la Vérité" and Barbara Johnson's "The Frame of Reference: Poe, Lacan, Derrida" ${ }^{8}$ have proved to be exceptionally influential in the chain of interpretation.

Inspired by these texts, I now have to take into account the motto's warning indeed: too much cunning is hateful to wisdom. In other words: the overcomplication of explanations might destroy the art of disentangling, which, according to Poe, is "that moral activity" in which the true "analyst" "glories." The only problem is: how much is too much? Where is the limit one must not transgress when trying to enter into a conversation with Poe's text, in order not to violate the "honour among thieves?" Poe, the master of proportion might offer us a helpful device in his review of Hawthorne's Twice-Told Tales: we might say that the interpretation, like a good story, must be "perusable" (i.e. readable and understandable) "at one sitting." 10

Yet also according to Poe, "These tales of ratiocination owe most of their popularity to being something in a new key."11 Perhaps it is not the amount but the mode of cunning that has to be dealt with cautiously, perhaps in this case "too much" is a qualitative and not a quantitative distinction. How to find the "new key" of cunning that is not incompatible with wisdom? We must try at least to be "wise as serpents and harmless as doves." ${ }^{2}$

5 John P. Muller and William Richardson, eds., The Purloined Poe: Lacan, Derrida E Psychoanalytic Reading (Baltimore and London: The Johns Hopkins University Press, 1988).

6 Jacques Lacan, The Seminar of Jacques Lacan, Book II, ed. Jacques-Alain Miller, trans. Sylvana Tomaselli (Cambridge: Cambridge University Press, 1988) 191-205.

7 Jacques Derrida, The Post Card: From Socrates to Freud and Beyond, trans. Alan Bass (Chicago: The University of Chicago Press, 1987) 411-497.

8 Barbara Johnson, "The Frame of Reference: Poe, Lacan, Derrida," Literature and Psychoanalysis, Yale French Studies 55/6 (1977) 457-505.

9 Poe says this in "The Murders in the Rue Morgue" (Mabbot, p. 528).

10E. A. Poe, "Twice-Told Tales, by Nathaniel Hawthorne, A Review," Anthology of American Literature, Vol. I, ed. George McMichael (New York: Macmillan Publishing Company, 1985), p. 995.

11 Poe wrote this in a letter to his friend, Philip Pendleton Cooke, 9th August 1846 (quoted in Mabbot, p. 521).

12 Cf. Matthew, 10:16 
The structure of the text is very much like that of a good detective story. There is a frame, a comfortable setting in which three people discuss a crime. Although there is a confidential Narrator, the events of the "crime story" are told first by the Prefect and then by the Detective (Dupin), so the first person Narrator loses his primary function and thus becomes a dubious and passive character. (The arabesque pattern of narrators might remind one of the structure of Scheherazade's tales in The Thousand and One Nights as well.)

The crime is very simple. In the royal "boudoir," a letter of great importance has been stolen from the Queen by the Minister who immediately replaced it by a letter of no value, and although she witnessed to the act of purloining, she was paralysed by the presence of the King, from whom the whole matter should be concealed. The matter requires extreme delicacy. (In fact, the words "Queen" and "King" do not appear in the text, they are referred to as "royal personages" and it is only the personal pronoun that differentiates them.)

This is a promising start, and the reader (whose trust is not yet stolen) immediately starts to make guesses of various importance. For example:

1. It is perfectly normal that a "Royal He" visits the boudoir of a "Royal She"

- but what has a Minister got to do there?

2. Even if it is the royal custom that state-affairs are discussed at this particular place of intimacy, how can the Minister have the courage to meddle with pieces of paper on the Queen's desk?

3. For what possible purpose does the Minister purloin the Queen's letter?

4. Who sent the letter and what is it about?

The reader might expect a "good detective story" to unfold along the lines of these (and similar) questions, but in Poe's text it is exactly this kind of information that is withheld. It is only the third of these miscellaneous naïve questions that can vaguely be answered: by stealing the letter, the Minister gains power over the Queen and has the possibility of blackmailing her into whatever he wants. But this possibility is never realised. As Lacan observes: "He [the Minister] suspends the power conferred on him by the letter in indeterminacy, he gives it no symbolic meaning, all he plays on is the fact that this mirage, this reciprocal fascination is established between himself and the Queen..."13

The letter gives the possibility of power to the person who holds it somewhat like Aladdin's lamp in the Arabian tale - but its 'jinni' is never let

13 Lacan, p. 200. 
loose, as if no one wanted to or knew how to do that. (This is not the only "lamp" Dupin decides not to use: when the Prefect enters, he literally stands up to light one in his room, but upon hearing the purpose of the visit, he sits down without doing so, preferring to think in the dark.)

There is no scandal, no juicy story to satisfy the reader's thirst (not necessarily for blood but for at least something to feel for, to identify with). Unless, of course, readers make it up for themselves. What Poe truly presents is a dry, although no doubt acrobatic display of "analytical" exercises, in which the main question is how to steal the letter back.

Meanwhile, he manages to sterilise the text of everything that would disturb the pure intellectual delight in the breathtaking flight of thought (of perfectly precise logic, blended with poetic intuition). But does the principle of l'art pour l'art (in this case, ratiocination for the sake of ratiocination) work without anything at stake, is it possible to enjoy the "supernal beauty" of the performance without the gravitation that attracts us to matters of life and death? If there is nothing at stake, there is nothing to lose when the delicate "luxury of meditation" (like the blue smoke of the meerschaum which is so enjoyable to Dupin, the Narrator and the Prefect) vanishes into thin air.

The text is extremely inviting because it is so seductive. It lures the reader into endless and comfortable philosophising, or else it succeeds in exciting one to the pleasures of bringing one's own analytic talent into play, and the passion for "disentangling" thus aroused can easily become an addiction. The absence of "heavy weight," that is, the absence of a proper story with flesh and blood characters, seems to allow us to free ourselves of human responsibility in the course of a literary analysis.

It is in this sense that instead of "mailing" a "manifold message," Poe manages to blackmail the reader: if we want to steal our trust in the power and weight of literature back, if we cannot remain content with the comfortable talk without human responsibility, we ourselves have to point out what is to be put at stake. This can be done either by entering an endless theoretical debate on what "literature" is, or by writing the missing story.

In both cases, we are confronted with the problem of delivery. If the purloined "letter" (now in the sense of the "heavy weight" described above) cannot be delivered by the "ordinary mail" of literature, how can it still, in Lacan's words, "reach its destination?" Is it possible that someone, equipped with exceptional rhetorical abilities, can conjure it up through the brilliant delivery of 
a speech? Or can someone's imagination conceive the seminal problem, and, after a pregnant silence, perform the successful delivery of a new-born story? Can we take Poe's text itself as a serve in an intellectual game of tennis, to be returned by a single, well-directed stroke? Or can we deliver ourselves from the problem, saying that the "heavy weight" we are so desperately looking for is simply nowhere to be found in Poe's text, and, like the helpless Prefect (who, by the way, is the single person in the story that might resemble a flesh-and-blood character) can we turn to an almighty master-detective who might show us that it has always already ("tojour déja") been there, under our very nose? (And what price are we willing to pay for that - either by filling a cheque or by way of "cash on delivery?")

How could we find a "new key" of understanding? If the attempt at solving a poetic problem (the search for cathartic experience) with the help of logic proves to be a failure, could we not experiment with making the problem a logical one and trying to solve it with the help of a touch of poetry? Since the Minister owes his unusual abilities to being both a mathematician and a poet, it might be useful to invite mathematics into the process of analysis, keeping in mind, of course, Dupin's outburst against "mere" mathematicians: "Mathematical axioms are not axioms of general truth. What is true of relation - of form and quantity - is often grossly false in regard to morals, for example."

Since the morals of the characters in this story, to say the least, can be questioned, it might be better to turn to their "relations." Let us take the plot to be that of a mathematical problem, in which the personae are geometrical points, definable only through their relations to the others. Poe's usage of initials instead of names (the Prefect G., the Minister D., the Sender S.) especially encourages me to do that - some of the characters have already been referred to by a single letter. I will take six characters into account. Three from the narrated scenes: the King = $\mathrm{K}$, the Queen $=\mathrm{Q}$ and the Minister $=\mathrm{M}$; and three from the scenes of narration: the Prefect $=\mathrm{P}$, Dupin $=\mathrm{D}$ and the Narrator $=\mathrm{N}$. When a "relationship," by which I strictly mean 'personal acquaintance,' exists between two points, they will be connected with a line. Step by step, out of these lines, some kind of a figure will have to develop. I will also take into account the measure of trust between characters; trust will only be geometrically interesting when the purloined letter (which I, unlike Lacan, do not consider to be a character) is set into motion.

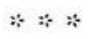


(1) Let me begin with the King $(\mathrm{K})$ - not only out of due respect but also because he seems to have the least to do with the all the others. This point is to be taken arbitrarily on the geometrical plane of the story. He is acquainted with the two other points: the Queen $(\mathrm{Q})$, who, in quite a conventional manner is subordinated to him (mostly by her fear of him), and the Minister (M) who, in turn, quite unconventionally seems to be in a co-ordinate relationship with him (since he can take liberties to such an extent in the royal boudoir). We do not learn whom the King trusts but, presumably, he trusts his Minister - and maybe he trusts the Queen as well, or at least this is what she hopes. The first figure is thus:

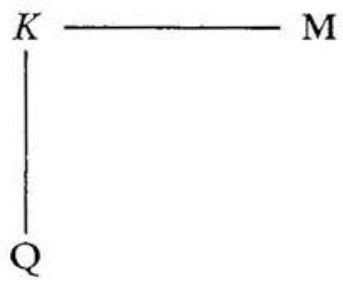

(2) The second point to be observed is the Queen's (Q), the single female character's. She is the only one for whom this game is a "matter of life and death" - but since the text does not reveal anything about her person, it is quite impossible to be moved by her intolerable predicament. She can be connected to three other points: the King $(\mathrm{K})$, the Minister $(\mathbf{M})$ and the Prefect $(\mathrm{P})$. Her marriage with the King is unstable: whatever went wrong between them gets manifested in the loss of the letter, which, unlike Desdemona's handkerchief, might truly become an "ocular proof" of her secret affairs. (The secret is not necessarily a love-affair - it might be a political issue or anything else, but it is certainly something that disconnects her from the King.) Consequently, she is afraid of her husband. Her connection with the Minister is even more problematic. By taking her letter, the Minister took her liberty. She is of course terribly frightened but - as Lacan observes - there might be a little exaggeration in her behaviour, unless she is emotionally more involved in her relationship with the Minister than the text allows us to know. The way she turns to the Prefect of the Police for help indicates that she is capable of complete trust, either in his personal discretion or in the efficiency of the institution. This trust creates a coordinate relationship between her and the Prefect: 


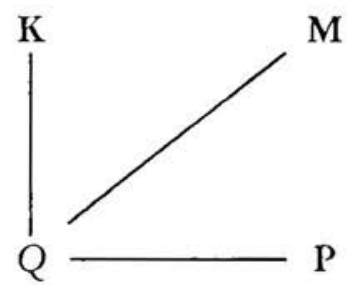

(3) The Minister $(\mathbf{M})$ is the next point to be examined, the one completing the triangle in the royal boudoir. He is connected with four persons: the King $(\mathrm{K})$, the Queen $(\mathrm{Q})$, the Prefect (P) and Dupin (D). Not only is he in a co-ordinate relationship with the King but, in the possession of the letter, he must feel even superior (at least in acumen). The way he is connected with the Queen, as we have seen, is quite problematic, mostly because his motives are unknown. Does this "monstrum horren. dum," this "unprincipled man of genius" (as Dupin calls him) play this game out of sheer boredom? Or can we suspect something more between him and the Queen? If I were to write the missing story, maybe he would be the Sender of the letter himself, and the Queen's agony would be due to the fact that she could not finish reading the letter - perhaps breaking their relationship off - when it was purloined. ${ }^{14}$

But this takes us far too far from geometry. The Minister's relation to the Prefect is quite clear: he can see through the Prefect's intentions and feels absolutely safe, in full awareness of his intellectual superiority. He is completely incapable of trust. But how does he feel about Dupin? Most probably, he takes the detective to be a worthy adversary, remembering the Vienna-incident between them in the past. But how is it possible that he does not suspect the return of the "evil turn" when Dupin enters his premises wearing "green spectacles?" Or is he so unprincipled that Dupin's machinations fit well into his plans because he got tired of his orwn game and wants to get rid of the wretched letter anyway? Be it so or not, it is beyond doubt that they are in a co-ordinate relationship. The third figure is thus:

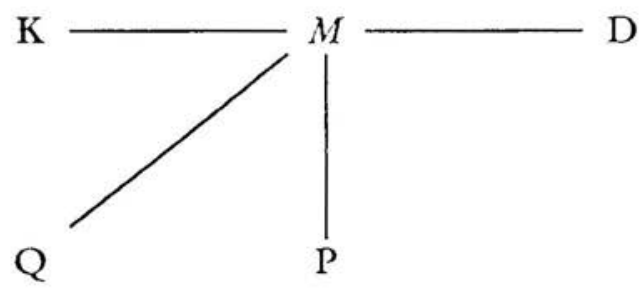

14 This idea was suggested by Géza Kállay. 
(4) Let me continue with the Prefect $(\mathrm{P})$, whose point constructs the connection between the narrated and the narrating personae. He, like the Minister is related to four other points, the Queen (Q) the Minister (M), Dupin (D), and the Narrator (N). He is perfectly loyal to the Queen, and rescuing her is his "knightly quest" (motivated, of course, just as much by his sympathy as by the prospect of the large financial reward). A down-to-earth, disciplined policeman, who does his best to fulfil his task. Although he is the typical "butt of jokes" in the intricately woven texture of this story, he is the only one capable of naive and hearty laughter: "Ha! ha! ha! - ha! ha! ha! - ho! ho! ho! [... ] oh, Dupin, you will be the death of me yet!" And he is right in a way: the natural and ordinary attitude to the world represented by him might be killed by the hyper-reflective way of thinking in the detective's analytical exercises. He is trustful, oddly enough, even of his opponent, the Minister, searching his house inch by inch, believing that by the perfection of his own method, he might find the letter. The "absolute legion of oddities" he lives among might as well be called miracles of various nature, simply because he is incapable of logically accepting anything outside his private, well-ordered universe. He is subordinated to the Minister and Dupin, due to his intellectual inferiority, and he is in a co-ordinate relationship with the Queen who trusts him, as well as with the Narrator, whom he tacitly trusts.

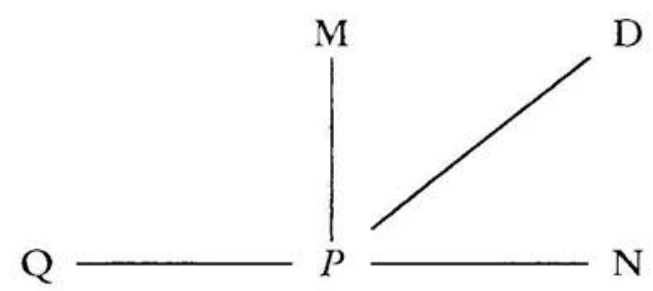

(5) Dupin's point (D) might be called the Archimedean "fulcrum" of this story (if such a term is compatible with the present experiment in Euclidean geometry), since Poe himself calls attention to the fact that "The reader is made to confound the ingenuity of the supposititious Dupin with that of the writer of the story." 15 Many critics observe that he is not only the Minister's "double" (having the same "lynx eye" and repeating the same trick) but the author's as well - on top of all that, as the Narrator of "The Murders in the Rue Morgue" says, he himself is a "Bi-Part Soul" with a double self: "the creative and the resolvent." If the word

15 Cf. Mabbot, p. 521. 
"resolvent" is meant in the sense of 'being able to separate, or divide,' then Dupin's two selves seem to repeat precisely the two inimitable divine activities expressed in the Book of Genesis (in King James' version) through the words "make/create" and "divide." How to place such a "point" on our two-dimensional geometrical plane? Following the Biblical line of thought: the human attempt at becoming God is the essence of sin. In what sense can Dupin's analytical exercises be considered to be sinful? Is there a sign of anything like that in the text? His diction, especially at the end of the story when his detached, impassive tone changes into a passionate and proud voice of self-complacency reminds us of the diction of some of Poe's criminal-narrators ("The Imp of the Perverse," "The Black Cat," or "The Tell-Tale Heart") all of whom give themselves away by the irrepressible pride over their ingenuity and security. As Stanley Cavell points out: "I am safe' is true as long as it is not said: saying refutes it." 16 And what he says about "skepticism" is of essential importance, since it may refer to the "perverse" game of analytical purloining as well:

What I am calling Poe's perverse account of skepticism does, I think, capture an essential perverseness in skepticism, at once granting an insight into skepticism and enacting a parody of it. The insight is that skepticism, the thing I mean by skepticism, is, or becomes necessarily paradoxical, the apparent denial of what is for all the world undeniable. I take skepticism not as the moral of a cautious science labouring to bring light into a superstitious, fanatical world, but as the recoil of a demonic reason, irrationally thinking to dominate the earth. I take it to begin as a wish not to reject the world but rather to establish it. The parody is to deny this, to conceal the longing for assurance under an allegedly more original wish for self-vexation. This concealment is revealed at the end of the confessional stories... ${ }^{17}$

It is in this sense that to some extent we can take "The Purloined Letter" to be "confessional." Dupin's "signature" to the Minister in the form of a quotation from Crebillon's Atrée et Thyeste (meaning something like "eat your own children," i.e. "you have fallen into your own trap" - or, as Lacan puts it in his interpretation: "Eat your Dasein!") is a sign of extraordinary sensitivity to the dangers of the analytical process. This final conceit, together with the later

16 Stanley Cavell, "Being Odd, Getting Even," In Quest of the Ordinary: Lines of Skepticism and Romanticism (Chicago and London: University of Chicago Press, 1988), p. 141.

17 Cavell, p. 138. 
inserted motto about "too much cunning" might testify to Poe's awareness and acknowledgement of the whole problem of skepticism.

Not forgetting about Dupin's "doubles," let us now turn back to geometry and single out a point for him on the chart - since, strictly speaking, he is a singular character with the primary function of the Detective in the story. $\mathrm{He}$, like the Queen, can be connected with three persons (all of whom are his shadows in a way): the Minister $(M)$, the Prefect $(P)$ and the Narrator $(N)$. Simply on the basis of intellectual superiority, the fifth figure looks like this:

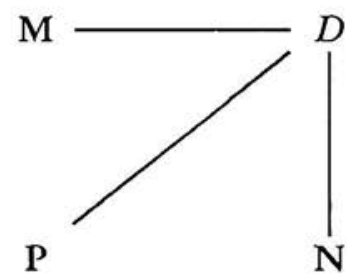

(6) The sixth and last character and point to be taken into account is the Narrator. $\mathrm{He}$, like the King, is an "outsider" - never touching the letter. (But there is a considerable difference between the two of them: whereas the King is involved in the matter without knowing about it, the Narrator knows about everything without being involved.) He, again like the King, has only two "connections": Dupin (D) and the Prefect (P). With them, he completes the triangle of the narrating personae. In the text, the most personal pronoun, "I," seems to be the least personal. $\mathrm{He}$ is so much of a shadow of Dupin that he seems to lack individual characteristics - and this is what makes him dubious. His relations are to be constructed thus:

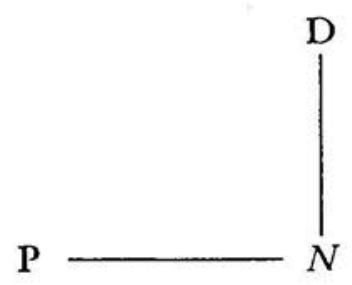


In the next two steps of the geometrical construction, I would first like to combine all the lines drawn so far, and then to suggest possible connections which are not strictly on the basis of personal acquaintance.

(7) What do we get if we put all the lines together in a figure?

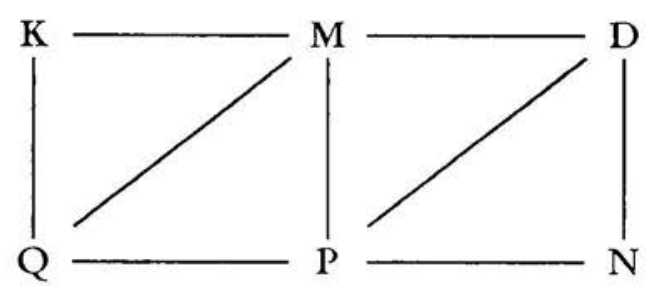

Although the lines are "doubled" because of the reciprocal relationships, the shape of a rectangle comes out, divided into four triangles, each of which represents one phase of the story. The first game of purloining involves KQM, the second (unsuccessful) attempt takes part between QMP, the third and crucial one happens between PMD, and the narrating scene - itself a game of purloining - is reflected in PDN. When the letter is set into motion, it takes its route clockwise along the lines of the QMDP parallelogram, and its direction is exactly in contrast with the directions of trust (up to the point we can follow it in the text, i.e. P since the fact that the Prefect takes it back to the Queen is presumable but never narrated). Points that share one line must share some features as well (e.g. QPN are intellectually or psychologically subordinated to KMD; QP are capable of complete trust as opposed to $\mathrm{MD}$; KQ's non-ideal marriage stands opposed to DN's ideal friendship, etc.)

(8) And what about other possible connections? The KP line could be drawn on the basis of their suspected or real naivveté, $\mathrm{MN}$ can be brought together by the fact that they both are doubles of Dupin. But the diagonals of this rectangle are important as well: KN are both outsiders (as described above); whereas DQ can be connected on the basis of their desire to take revenge on $\mathbf{M}$.

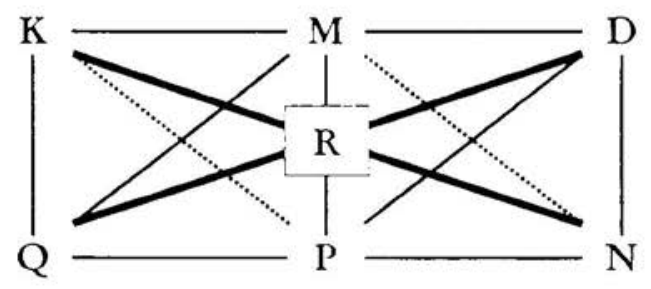


The figure we have thus received strangely reflects the shape of a folded and re-folded envelope (maybe somewhat "more chafed than [... ] necessary"). It could be sealed in the intersection of the diagonals and the MP-line: let me name this point $\mathrm{R}$ for Reader. What do we expect to find in this final envelope? A cheque of fifty thousand francs? A message letting us know that by such experiments we are, in a sense, "eating up our own children?" Or a letter of great importance, which indeed has reached its destination and hopefully will never be purloined? But what if the envelope is empty? Even in that case, we might see it as an envelope exposed to our mercy, and the responsibility of filling it or throwing it away (facing it or avoiding it in the Cavellian sense) is ours. 